\title{
The Symbolic Forms of Indonesian Language Teaching's Discourse at IAIN Palopo: A Critical Discourse Analysis
}

\author{
Sukirman \\ Universitas Negeri Makassar, Jln. Bonto Langkasa, Kampus Gunung Sari, Makassar, South Sulawesi, Indonesia \\ Jufri \\ Universitas Negeri Makassar, Jln. Bonto Langkasa, Kampus Gunung Sari, Makassar, South Sulawesi, Indonesia \\ Suradi Tahmir \\ Universitas Negeri Makassar, Jln. Bonto Langkasa, Kampus Gunung Sari, Makassar, South Sulawesi, Indonesia \\ Mahmudah \\ Universitas Negeri Makassar, Jln. Bonto Langkasa, Kampus Gunung Sari, Makassar, South Sulawesi, Indonesia
}

\begin{abstract}
This research aims at revealing the functions of symbolic forms of Indonesian language teaching $(P B I)$. The method used is qualitative descriptive with data source in the form of conversations between lecturer and students who produce words, phrases, and sentences obtained by recorder instrument (handycam) and interview guidelines. The data is analyzed using data reduction, data display, and verification technique. The results show that the symbolic forms used in PBI's discourse reveals the idea of characteristics concerning motivation, strengthening, competence, sharpening, and awareness. In line with that, the functions of the symbolic forms include (1) statements with "challenging" characteristic and its development; (2) direction, guidance, and advice; (3) praise; (4) threat (fear); (5) question and correction; (6) inadequacy and weakness; (7) sanction (discipline); (8) counseling and training service; (9) instruction or command; (10) honesty; and (11) request or demand.
\end{abstract}

Index Terms-symbolic forms, PBI's discourse, critical discourse analysis

\section{INTRODUCTION}

Language as an action in communicating is closely related to characteristic's development and academic cultural behavior in higher education. Therefore, Indonesian language is one of the crucial instruments in the science and technology advancement. Thus, it has a role and function as a medium of communication in the world of education. This is explained in Law Number 24 Year 2009 Article 29 Paragraph 1 that Indonesian language must be used as the language of instruction in national education.

This occasion creates a special phenomenon. In other words, changes in social and cultural behavior of society affect the way people think and act. In expressing the intent, language is often shaped to be used to package meaning through text or discourse, both in writing and orally. As what has been confirmed by Rusdiati (2003, p.38) that the phenomenon of language use by Bourdieu referred to as "symbolic violence", which means violence gains compliance and not perceived as coercion.

Language action in a learning space often produces an idea (ideology) which makes categorization from moderate to radical thinking. This is due to the academic community in higher institution specifically at Institut Agama Islam Negeri Palopo (abbreviated as IAIN Palopo) which involves several ethnic groups and later causes multiculture. Accordingly, conflicts are unavoidable as well because those parties have mutual interest to embed their own influence and power. Fairclough (1989) confirms that to spread new influences or ideologies, then both individual and group shall use language as a medium where text (symbolic form) becomes a form of social practice.

In the view of critical discourse, all aspects of a text (words and grammar) are empowered to encapsulate certain interests (ideology and power) to be conveyed in speech interaction, such as between speaker and receiver. The disclosure of symbolic violence that lies behind a text of speech requires an attempt to liberate the language spoken by a speaker in conversational or textual interactions. It leads the use of critical discourse as an analytical tool to uncover the hidden ideology and power produced in text as a language action in a learning space.

The power of language in symbolic form becomes the subject matter and orientation of this research by focusing on the function aspect of Indonesian language. Several aspects of symbolic forms are used as empowerment of language action in learning which influenced by multicultural and pluralistic elements. In addition, some factors of geographic environment, speaker position, atmosphere or context of speech acts have an effect as well. The symbolic forms 
produced in language action are driven by forms of interest, particularly ideology, power, and domination. The use of language in symbolic form is a deviation from the actual language due to an element of concealment from the real meaning.

The phenomenon of language in symbolic form produced in the language action between lecturer and students becomes important to be studied because it avoids the emergence of different meaning interpretation phenomena, both in academic community and in varied groups of society. Referring to these facts, the study of symbolic form in verbal language turns to be one of the essential aspects. It is intended for the purpose of communication and information where a statement can take place in harmony due to the similarity of intent and understanding between speaker and receiver. Thereupon, examining the symbolic form will reveal and lead to the understanding of implicit meaning.

The symbolic forms produced in the text of language action between lecturer and students taking place in the learning process can be studied using a critical discourse approach. Badara (2013, p.65) argues that by the use of critical discourse analysis framework approach, it can reveal the things implied behind the apparent reality. To observe the specific and in-depth symbolic form in language action between students and lecturer, it uses the theory of Bourdieu, Fairclough, and van Dijk. Those three theories are combined and for the purposes of the analysis, they are modified in the eclectic or theoretical form to expose the hidden symbolic form function of a text.

The study of symbolic forms in Indonesian language is indispensable to uncover and comprehend the clarity of hidden ideology and power behind verbal texts. If it is not done, it will lead the purpose of communication into unclear ones because of differences in understanding meaning of the text. Finally, those differences and disagreements cause to conflict. Equally important, academic community will not know the function and symbolic form they use in speech acts. They are only able to use symbolic forms in social practice, but lack of knowledge and understanding of the symbolic placement in a conversation. In the same way, here is the problem statement of this research, what are the functions of symbolic forms of Indonesian language teaching's (PBI) discourse at IAIN Palopo?

\section{RESEARCH METHODOLOGY}

This research employs qualitative design because the data is obtained through natural setting and directly from complete and thorough research subject without any changes or data modification. The function and benefits of qualitative research are used to examine something in depth (Moleong, 2011, p.7). As described by Denzin \& Yvonna S. Lincoln (2009, p.1), a qualitative research links with cultural and interpretative researches. Thus, this research is included as a qualitative research because it aims to examine the details and do the interpretation of the symbolic forms in Indonesian language teaching's discourse which found during oral learning interaction as a language action at IAIN Palopo.

Pursuing this further, it uses descriptive qualitative design due to seven factors. The first thing is, the data sources are natural because there is no interference of the researchers in the process of its creation. The second is the researchers as the key instruments also become as the assessors. The third is the data exposure or discussion is interpretative. The fourth is data analysis is done interactively. The fifth is the representation, type, and function of symbolic forms in Indonesian language become the main concern of this research. The sixth is the theory only used as an analytical instruction. The seventh is arranging theories becomes an optional because it is only used as an analytical instruction (Mulyana, 2003, p.159; Bogdan and Biklen, 1998, p.4-7).

This research data is in the form of words, phrases, clauses, and sentences as primary data which consist of symbolic forms generated from oral text in a speech adapted through recorder, while the secondary data derived from experts' research findings and articles regarding the analysis of symbolic form to support the data. Several procedures and the design stages of research activities include recording, transcription, supporting instruments, data corpus, data reduction, results, discussion, and findings.

The instruments used to collect data such as (1) the researchers who act as an instrument (planner, executor, and data interpreter); (2) handycam as a data recorder to record and capture lecturer's and students' conversation during learning process; (3) statements or questions as the interview guidelines to collect answers for supporting the data research.

The validity of research data is examined based on five factors such as researcher's persistence, reference adequacy, suitability or data coverage, extension of data observation toward the recorded data, and data validation by experts in this field of research. The data were analyzed with a critical discourse analysis approach which is done in three stages, that is data reduction, data display, and conclusion or verification (Sugiyono, 2011, p.247-253).

\section{FINDINGS AND DISCUSSION}

In this section, the results of the research is described in the form of clarified data. The following discussion is based on the data description.

\section{A. The Description of Research Findings}

The symbolic forms are used to express violent meaning behind the spoken statements by lecturer and students. It aims to "sharpen or harden" meaning in PBI's discourse.

1. The Statements with "Challenging" Characteristic and Its Development 
The following statement in PBI's discourse reveals the symbolic form of expressing the meaning of "challenging" and its development. Here is the statement below.

Data (1)

"Ayo, mana pikiran Anda mahasiswa? Anda berlatih bagaimana Anda berargumen, bagaimana Anda mengolah pikiran? Kemudian paling cocok lewat lisan. Jangan hanya disimpan dalam otak.” (UK II.6/12)

(Translation)

"Come on, where do you put your mind, students? You practice how to argue, how to process in mind? Then it is best expressed through speak. Do not just keep it in mind." (UK II.6/12)

The sentence in data (1) shows that the meaning in the form of "challenging" or the development of competence as the main subject of the conversation is 'Ayo, mana pikiran Anda mahasiswa?' (Come on, where do you put your mind, students?). The lecturer as a speaker expresses the idea in the form of affirmation that emphasizes the ability to think and speak. In this case, he "challenges" the students with the statement where it contains the idea of strengthening the nature of giving pressure to the students to be more creative and productive in speaking. It is also clarified with a statement of '...bagaimana Anda mengolah pikiran? Kemudian paling cocok lewat lisan.' (how to process in mind? Then it is best expressed through speak.). Furthermore, it is reinforced through the statement of 'Jangan hanya disimpan dalam otak.' (Do not just keep it in mind.). Through the description above, it indicates that the lecturer as a speaker gives a "challenging" emphasis with an intention as one strategy to awaken, encourage, trigger enthusiasm, and direct student's identity in expressing the ability to speak.

2. Giving Direction, Guidance, and Advice

The following statement in PBI's discourse is expressed in symbolic forms of directing, guiding, and giving advice function. Here is the statement below.

Data (2)

"Kadang mahasiswa lebih senang diisi ya, tetapi tidak senang apabila kalian mencari sendiri. Padahal terbalik, kalian harus lebih merasa senang apabila kalian mencari sendiri, dan nantinya akan diperkuat oleh keterangan dosen. Nah, itu yang diharapkan ya, dari aktivitas perkuliahan kita. Bisakah kita bekerja sama saling mengisi." (UK I.1/2)

(Translation)

"Sometimes students prefer to be dictated, right, and not keen to find out by their own self. As reversed, you should be more pleased if you can figure something out by your own self, and later will be supplemented by lecturer's information. Well, that's what we hope, right, from our lectures activity. Can we cooperate with each other to nurture." (UK I.1/2)

The sentence in data (2) shows that the meaning in the form of guiding as the main subject of the conversation is '...kalian harus lebih merasa senang apabila kalian mencari sendiri,...' (you should be more pleased if you figure something out by your own self). Lecturer as a speaker expresses ideas in the form of motivation or affirmation. It tends to give direction by expressing the statement where the speaker gives great respect and high motivation to students who are more creative and innovative. In this regard, the lecturer as a speaker suggests and invites the students to change their mindset to a more independent thinking by using modality of 'harus' (must/should be). Thus, the idea or thinking structure of the speaker expressed through the data description confirms that motivation or affirmation embodied in the form of direction aims at creating a more innovative mindset.

3. Giving Praise

The following statement in PBI's discourse is expressed in symbolic forms of giving praise or compliment. Here is the statement below.

Data (3)

Dosen

Mahasiswa

: “Ini diskusinya kelompok dua sangat memuaskan."

(Translation)

Lecturer

Students

: "Hu...." (IW IV.1/10)

: "Group two manages the discussion excellently."

: "Boo...." (IW IV.1/10)

The sentence in data (3) shows that the meaning in the form of giving praise as the main subject of the conversation is 'Ini diskusinya kelompok dua sangat memuaskan.' ("Group two manages the discussion excellently.") where the lecturer as a speaker expresses the idea of affirmation or motivation as well. It is made clear by the word option of 'sangat memuaskan' (excellent). Thus, it indicates that the discussion delivered by the students from group two referred as great and successful which makes it excellent by the lecturer. The objectives or ideas form of affirmation and motivation are the lecturer as a speaker convinces the students that the discussion managed by them shows a maximum result. Therefore, such activities can be rearranged because the presentation and analysis of language errors run decently and give a maximum result.

4. Giving Threat (Fear)

The following statement in PBI's discourse is expressed in symbolic forms of giving threat or fear. Here is the statement below.

Data (4) 


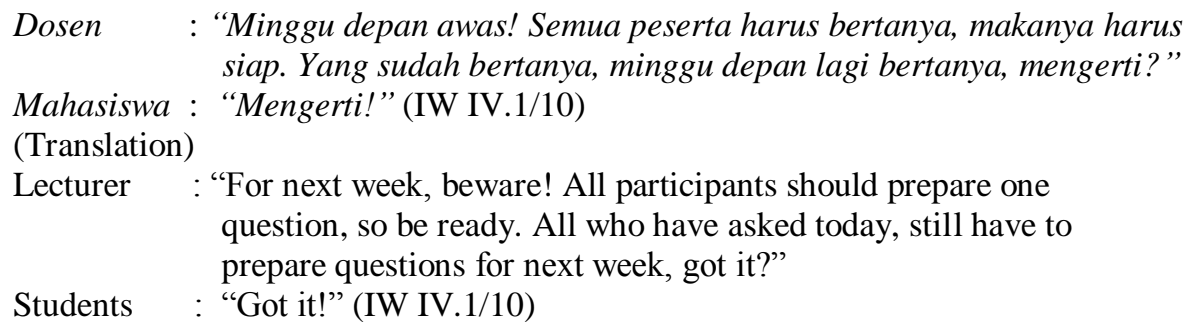

The sentence in data (4) shows that the meaning in the form of giving threat or fear as the main subject of the conversation is 'Minggu depan awas!' ("For next week, beware!'). The lecturer as a speaker expresses a threat to the receivers. Even so, it can be seen that the emphasis from the word option of 'awas' (beware) indicates that the idea expressed by the lecturer as a speaker becomes the form of prudence and readiness as all the participants should get a turn to ask. It is intended for all participants to be active in the discussion where they are expected to think critically and creatively in formulating questions. The form of threat and force by the lecturer as a speaker is intended to terrify the students so they can change attitudes and thoughts into more creative and useful. This method is chosen by the speaker to reinforce and encourage responsiveness to improve teaching quality for maximum results. The encouragement is done by giving threatening situation, which is to provide affirmation to the students. The idea of prudence and readiness becomes affirmation in shaping and embedding attitudes toward competence mastery and increased ability to express thoughts or opinions as a manifestation of maximum teaching results.

The following data excerpt expressed by the speaker shows resentment which implies an impropriety event so he threatens the students.

Data (5)

"Apakah dia merupakan bahasa yang baik dan benar? Okelah, kalau begitu kapan dia berbahasa Indonesia yang baik dan benar? Ayo, masa' empat puluh otak tidak ada, hanya dua orang yang bisa menjawab. Yang di belakang coba! Apa itu Nak? Apa itu? Hai'! Nanti kalau saya kasih masuk di ujian, cari memangko [memang] jawabannya. Nanti, kalau saya kasih masuk di soal semester, segera kau cari jawabannya." (BAK I.3/6)

(Translation)

"Is it a correct and proper language? Alright, so when does he speak Indonesian correctly and properly? Come on, forty brains do not exist, only two of you who can answer. You at the backseat! What is it, Boy? What is that? Tck! Later if I include this question to exam, find the answer (seriously). Later, if I include this in final exam, immediately find the answer." (BAK I.3 / 6).

The sentence in data (5) shows that the meaning in the form of giving threat or terror as the main subject of the conversation is 'Nanti kalau saya kasih masuk di ujian, cari memangko [memang] jawabannya. Nanti, kalau saya kasih masuk di soal semester, segera kau cari jawabannya.' ("Later if I include this question to exam, find the answer (seriously). Later, if I include this in final exam, immediately find the answer.") The lecturer as a speaker shows a sense of resentment towards the absence of response from the students as the receivers. A situation and condition of a lecture which do not produce desired responses or answers by the lecturer as a speaker threatens through the statement. It is intended to terrify and force the students that the question will be tested in final exam. The intention of the speaker through the statement is the students should be more active, creative, and competent in learning Indonesian language. Hence, the idea delivered by the lecturer as a speaker is prudence and readiness which is to motivate and encourage the students to prepare themselves and change the pattern of bad learning behavior.

5. Giving Question and Correction

The following statement in PBI's discourse is expressed in symbolic forms of giving question and correction. Here is the statement below.

Data (6)

Mahasiswa: "E, begini sebenarnya saya bertanya di sini untuk menguji. Jadi, saya hanya ingin memberikan pemahaman kepada teman-teman bahwa kelebihan dan kekurangan buku yang pertama kalau kelebihan itu...." (IW IV.3/10)

(Translation)

A Student: "Um, here is the thing, I actually asked here to test. So, I just want to give my friends an understanding that the advantages and weaknesses of the first book, where its advantages are...." (IW IV.3 / 10)

The sentence in data (6) shows that the meaning in the form of giving question and correction as the main subject of the conversation is '... bertanya di sini untuk menguji. Jadi, saya hanya ingin memberikan pemahaman....' ('asked here to test. So, I just want to give my friends an understanding....'). The student as a speaker expresses the idea in the form of competence or knowledge to other students as the discussion's participants which clarified through the statement. It shows that the raised question is used as a strategy to share speaker's competence to the other as receivers in such activities related to the books' advantages and weaknesses. Therefore, the purpose of the question form is to enforce learning activities.

6. Stating Inadequacy and Weakness 
The following statement in PBI's discourse is expressed in symbolic forms of stating inadequacy and weakness. Here is the statement below.

Data (7)

"Pengamatan kita itu saja yang sering bicara, yang kita lakukan sekarang. Manakah suara yang tidak bersuara itu mengajukan pendapat. Ada apa denganmu sehingga kamu tidak bisa mengungkapkan pemikiran lewat diskusi yang biasanya kita terapkan di setiap kali pertemuan. Nah, siapa perwakilan ataukah, beberapa orang dari temanmu bisa mengungkapkan kenapa Anda diam." (UK II.7/2)

(Translation)

"All that we can witness only those who often speak, which we do now. Where are those voiceless people who speak their voice. What is wrong with you that makes you cannot express thoughts through regular discussions we usually conduct every meeting. Well, who is the representative, or, some of you here can tell why you keep silent." (UK II.7 / 2)

The sentence in data (7) shows that the meaning in the form of stating inadequacy and weakness as the main subject of the conversation is '...itu saja yang sering bicara, yang kita lakukan sekarang. Manakah suara yang tidak bersuara itu mengajukan pendapat. Ada apa denganmu sehingga kamu tidak bisa mengungkapkan pemikiran lewat diskusi....' ('...only those who often speak, which we do now. Where are those voiceless people who speak their voice. What is wrong with you that makes you cannot express thoughts through regular discussions...."). The lecturer as a speaker expresses the idea of strengthening or affirmation form to the students as receivers. It is known through an emphasis using the lecturer's question form as the speaker who declares what causes some students as the receivers cannot speak up their thoughts through the discussion activity. From that statement, the lecturer as a speaker identifies the form of inadequacy and weakness in students. It is clarified through a statement of '...siapa perwakilan ataukah, beberapa orang dari temanmu bisa mengungkapkan kenapa Anda diam.' (...who is the representative, or, some of you here can tell why you keep silent.). In this matter, the lecturer tries to show inadequacy and weakness for encouragement and stimulation to be more creative and skilled in thinking and speaking. He states the students' weakness or incapacity as a form of strengthening to encourage and motivate them so they can qualify and adjust the procedures of learning activities well.

7. Giving Sanction (Maintaining Discipline)

The following statement in PBI's discourse is expressed in symbolic forms of giving sanction or maintaining discipline. Here is the statement below.

Data (8)

\begin{tabular}{|c|c|}
\hline Mahasiswa & : “Assalamu'alaikum warahmatullaahi wabarakaatuh.” \\
\hline Dosen & $\begin{array}{l}\text { : "Wa'alaikum salam, Ade' yang baru masuk, boleh masuk, tapi } \\
\text { absen dikatakan alpa. Mau masuk atau tidak?" (UK I.5/3) }\end{array}$ \\
\hline & \\
\hline A Student & : "Assalamu’alaikum warahmatullaahi wabarakaatuh.” \\
\hline Lecturer & $\begin{array}{l}\text { : “Wa'alaikum salam, The girl who just entered, can stay in the } \\
\text { class, but in Student's Roll, you will be absent. So you want } \\
\text { to join the class or not?" (UK I.5/3) }\end{array}$ \\
\hline
\end{tabular}

Data (9)

"Terlambat Nak, lain kali masuk ya." (BAK I.3/1)

(Translation)

"You are late, Kid. Next time you have to join the class." (BAK I.3/1)

Data (10)

"Kemudian, saya juga perhatikan itu. Jadi itu absen saya kalau lewat mi (melewati waktu) kesepakatan jangan kasih tanda tangan di'. Siapa yang pegang absen saya dia bertanggung jawab nah. ”(MG I.1/4)

(Translation)

"Then, I also noticed. If students' attendance have been checked, we have to agree to not let the students who come late to put their sign in Student's Roll. Who holds the Student's Roll will be responsible for that."

(MG I.1/4)

The sentences in data (8), (9), and (10) show that the meaning in the form of giving sanction or maintaining discipline as the main subject of the conversations are '...boleh masuk, tapi di absen dikatakan alpa.' ('...can stay in the class, but in Student's Roll, $u$ will be absent.'), 'Terlambat Nak, lain kali masuk...' ('You are late, Kid. Next time you have to join the class....'), '...kalau lewat mi (melewati waktu) kesepakatan jangan kasih tanda tangan....' ('...we have to agree to not let the students who come late to put their sign in Student's Roll...'). The lecturer as a speaker shows that his idea or thought is expressed in the form of firmness with regard to discipline. In the explanation, the lecturer as the speaker emphasizes the timeliness associated with students' attendance in learning activity. Thus, the form of symbolic form which the speaker wants to express is the obedience to the agreement. Therefore, if there is a student who comes late, he or she will be given a sanction which aimed at showing a sense of regret to awaken an attitude of consciousness so as not to repeat the same thing. By that way, giving sanction or discipline is an effort to build a sense of awareness and obedience toward the rules to be encouraged in teaching activities. 
8. Provision of Counseling and Training Service

The following statement in PBI's discourse is expressed in symbolic forms of providing counseling and training service. Here is the statement below.

Data (11)

Dosen: “...kalian Ibu suka, bagaimana Anda mengembangkan pola pikir, bukan Anda mengatakan 'iya sudah'. 'Moderator lanjut! Materi...' aduh! Bukan begitu yang Ibu Inginkan...kalau seperti, langsung diberikan, tetapi bagaimana Anda melatih lisan Anda berargumen. Bagaimana Anda dalam sosok mahasiswa yang akan memberikan pendapat-pendapat yang logis mengenai suatu hal memecahkan masalah. Jangan seperti orang yang baru belajar berbicara." (UK II.6/23)

(Translation)

Female Lecturer: "You all, I prefer, how you develop mindset, not just saying, 'that's enough'. 'Moderator, continue! The material...' Oh! That's not what I want...if it is like, continue the reading, but how you practice your oral argument. How do you as a student provide logical statement on solving a problem. Do not be like a person who just learns to speak." (UK II.6 / 23)

The sentence in data (11) shows that the meaning in the form of providing counseling and training service as the main subject of the conversation is '...melatih lisan Anda berargumen. Bagaimana Anda dalam sosok mahasiswa yang akan memberikan pendapat-pendapat yang logis....' ('...practice your oral argument. How do you as a student provide logical statement....'). The lecturer as a speaker expresses her ideas or thoughts in the form of affirmation which is more emphasized on the process of counseling service aims at influencing and giving comprehension the students as receivers about the importance of practicing oral argument and provide logical statements. From that point, it is understood as a statement of ideas or more technical thoughts where it is expected to have the power in triggering enthusiasm and having creative and productive attitude for speaking ability. Thus, the idea is more directed toward the process of technical, interactive, and applicable counseling and training service which aims at providing affirmation to the students.

9. Giving Instruction or Command

The following statement in PBI's discourse is expressed in symbolic forms of giving instruction or command. Here is the statement below.

Data (12)

Mahasiswa: 'E, manfaat rangkuman memudahkan, ndak kutahu je' (saya tidak tahu) berapa Pak, tapi yang...."

Dosen :Iya, sebut saja yang ada di kepala Anda! Sebut!” (IW IV.3/13)

(Translation)

A Student : "Er, the benefits of a summary is to make it easier, I dont know how many points are them Sir, but the...."

Lecturer : "Yes, just mention what pops in your mind! Mention it!" (IW IV.3 / 13)

The sentence in data (12) shows that the meaning in the form of giving instruction or command as the main subject of the conversation '...sebut saja yang ada di kepala Anda!' ('...just mention what pops in your mind!'). The form expresses the instruction of an emphasis with the function to strengthen so that the sudents' ability and self-confidence increase. Therefore, the structure that the lecturer conveys as a speaker where its idea's construction contains a statement of command and affirmation is to make the receivers respond immediately. The statement above greatly confirms the form of affirmation which means to just express what you know with no doubt about the incorrect answer. The purpose of affirming idea is to give students confidence in answering questions.

10. Declaring Honesty

The following statement in PBI's discourse is expressed in symbolic forms of declaring honesty. Here is the statement below.

Data (13)

"Saya suka sekali lisan, kenapa? Lisan itu ketika ujian lisan bagus. Kenapa saya bahasakan itu, karena hasil pemikiran sendiri, kalau tulisan banyak mencontek." (IW I.4/4)

(Translation)

"I appreciate oral speaking much, why? It is good when conducting oral exams. Why I say that, because it is the results of our own thoughts, a written exam has a bigger chance to cheat." (IW I.4 / 4).

The sentence in data (13) shows that the meaning in the form of declaring honesty as the main subject of the conversation is 'karena hasil pemikiran sendiri,' ('because it is the results of our own thoughts, '). The lecturer as a speaker also expresses the idea of strengthening form through honest attitude to make an emphasis by using expressive and rhetorical question, that is 'Saya suka sekali lisan, kenapa?' ('I appreciate oral speaking much, why?'). The statement shows that the lecturer as a speaker tries to convince students as receivers of oral test's benefit due to the results of own thought which is different to written exam with a bigger chance to cheat. Thus, the lecturer as a speaker expresses the idea of reinforcing the attitude of honesty by comparing between oral and written exams. Through the comparison, the lecturer can motivate students in teaching and learning activity. Clearly, honesty can evoke critical and comprehensive curiosity which creates confidence as well in dealing with teaching activities. Therefore, developing an 
attitude of honesty in conducting teaching is one way of building character as a motivation and affirmation of the students.

11. Asking for Request or Demand

The following statement in PBI's discourse is expressed in symbolic forms of asking for request or demand. Here is the statement below.

Data (14)

Mahasiswa

Dosen

: "Assalamu'alaikum warahmatullaahi wabarakaatuh."

Mahasiswa

: "Masuk! Wa'alaikumsalam, ada yang bisa saya bantu?"

: "Ibu, maaf terlambat ki' (terlambat) datang karena ada teman yang kecelakaan tadi Bu'.” (UK I.5/4)

(Translation)

A Student

Lecturer

: "Assalamu'alaikum warahmatullaahi wabarakaatuh."

A Student

: “Come in! Wa'alaikumsalam, can I help you?"

: "Ma'am, sorry for coming late because my friend had an

accident, Ma'am." (UK I.5 / 4)

The sentence in data (14) shows that the meaning in the form of asking for request or demand as the main subject of the conversation is 'Ibu, maaf terlambat ki' ('Ma'am, sorry for coming late...'). The student as a speaker shows her idea or thought which expressed through an apology statement that followed by an explanation of her friend's accident as her reason for coming late. It shows that the student as a speaker expresses the idea in the form of affirmation to her lateness with reason to be understood by the lecturer. Therefore, the ability to improve lies in the argumentation of making a logical reason with the aim of convincing the lecturer to be allowed in attending lecture's activity.

\section{B. Further Description of Research Findings}

Based on the data results in PBI's discourse, eleven functions of symbolic forms are expressed by the speakers as the formation of character building which include (1) statements with "challenging" characteristic and its development; (2) giving direction, guidance, and advice; (3) giving praise; (4) giving threat (fear); (5) giving question and correction; (6) stating inadequacy and weakness; (7) giving sanction (discipline); (8) providing counseling and training service; (9) giving instruction or command; (10) declaring honesty; and (11) asking for request or demand.

The eleventh description of the symbolic functions differ from Ritzer's (2014, p.630-631) which describes the general function of symbolic forms into four functions, such as (1) giving people the ability to recognize the material and social world of understanding the environment; (2) improving the ability to think because language can broaden knowledge; (3) improving human's ability to solve any problems; and (4) the use of symbols from actors who can visualize a metaphysical reality. In addition, it also differs from Yule's statement (2014: 93-94) which classifies the meaning of general speech acts into five functions, that is (1) declarative function; (2) representative function; (3) expressive function; (4) ) directive function; and (5) commissive function.

The function of symbolic form delivered by speakers in PBI's discourse where its substance expresses characters about morals, affirmation, motivation, and self-development which also shows positive image behaviors. This is confirmed by Adisusilo, (2014, p.2) that moral behavior is basically something covered in one's mind because it is stored in the way of thinking. Therefore, by just looking at personal appearance, it will be not enough to apprehend which is the moral reasoning behind his behavior. Thus, it is necessary to examine a deep critical discourse to reveal the character form behind an idea.

The developed character by speaker in PBI's discourse shows the critical attitude of scientific thinking. This is agreed by Zubaedi's (2011, p.10) statement that character refers to a series of attitude, behavior, motivation, and skill. It includes attitude, desire to do the best, and intellectual capacity, such as critical and moral reason, behavior, honest, and responsible. It is shown through an interview with a lecturer about the condition of Indonesian language learning.

"Kalau menurut saya Pak kondisinya, kecakapan berbahasa untuk mahasiswa sendiri sebenarnya mereka belum sepenuhnya. Dan ini tantangan saya selaku dosen bahasa Indonesia. Di sinilah saya harus mengajarkannya. Apalagi mata kuliah Bahasa Indonesia memang keterampilan berbahasa, itu adalah salah satu e, pembelajaran yang harus saya berikan kepada mahasiswa dan, sepertinya aspek berbahasa dan aspek menulis yang sangat perlu saya tekankan pada mahasiswa".

(Translation)

"From my perspective, Sir, the condition of, language proficiency for students themselves actually they are not fully capable. And this is my challenge as an Indonesian language lecturer. This is where I have to teach. Moreover, Indonesian Language course is a language skill, it is one of err, the learning that I have to give to the students and, it seems the language aspect and writing aspect are the most thing that I should force to the students."

The explanation above which is under the lecturers' concern when teaching Indonesian language involves a high motivation to build students' intellectual character especially in language proficiency skill. Thus, the effort of giving motivation and affirmation in PBI's discourse is an effective way of building moral values through attitude and cognition. This is according to Naim's statement, (2012, p.57) that the character must always be maintained, defended, and grown. Therefore, the provision of motivation and reinforcement is one of the effective attitudes to encourage the improvement of creative and critical thinking in PBI's discourse. The statement is also supported by Marzuki (2015, 
p.23) that without the intelligent effort of character education, it will not produce intelligent people who at once are able to use their intelligence to act and behave properly. This is in accordance with an interview result from a lecturer who explains about some difficulties in teaching.

"Kesulitan pasti ada Pak, tapi kesulitan bisa diminimalkan. Kesulitan itu apabila mahasiswa tidak bisa mengeluarkan pendapatnya. Pak itu yang biasa agak mempersulit saya sebagai dosen untuk mengajar. Kadang beberapa orang yang mampu mengungkapkan hasil pemikiran mereka, sedangkan yang lainnya itu hanya menyimak apa yang disampaikan oleh teman ataupun dosen".

(Translation)

"Difficulties are unavoidable Sir, but it can be minimized. The difficulty is if students cannot express their opinions. Sir, that is a usual barrier for me as a lecturer when teaching. Sometimes only several students are able to express their thoughts, while the others only listen to what is delivered by their classmates or lecturer."

Yet another reason why, the results of the interviews shows that lecturers in teaching Indonesian language find it difficult to encourage students to be actively involved in speaking to express opinions, but then it is minimized and succesful to overcome such difficulties. This also indicates that the lecturers make a smart effort to find the right strategy. Specifically to overcome the difficulty as a step of character building in improving the ability to speak up.

The symbolic form expressed in PBI's discourse is able to build the character of scientific thinking and encourage students to be positive in overcoming difficulties during teaching and learning process. This can be observed in an interview result with a student about his difficulties during teaching and learning process.

"Ada beberapa dosen menyampaikan bahasa ilmiah yang baru kita dengar, tetapi itu menjadi acuan bagi kita semua untuk mengetahui apa makna dari bahasa ilmiah itu. Jadi, dijadikan sebagai pembelajaran”.

(Translation)

"There are some lecturers who deliver new scientific terms to our ear, but it becomes reference for all of us to discover what actually the terms mean. So, it becomes as a learning material."

The interview result shows that the difficulties found by the students in learning process become as motivation to be more active. Additionally, it is used as a challenge to build self-image into a more positive direction for scientific competence. This is in accordance with the statement of Zuchdi et al. (2013, p.9) that the most important thing to teach is problem-solving skill, critical and creative thinking, and making decisions with full responsibility. Thus, the statements from the interview shows that there is a violent meaning conveyed in symbolic form where the difficulty used as a learning interpreted into the creative and critical way of thinking for solving problem.

The effort to build a good atmosphere and interaction structure in PBI's discourse is one effort to develop positive thinking insight. This is shown in the student's statement through the interview, "...I think when we are in a good environment, we will automatically also direct ourselves to good things as well." Thus, an effective teaching environment will affect students' character building toward positive things. Moreover, the creation of teaching environment and atmosphere can be utilized as a reinforcement and motivation. This is supported by Marzuki's (2015, p.42) that teacher or lecturer should create a conducive learning environment so that teaching can run effectively in a safe, active, creative, democratic learning environment which supported by discipline, honesty, and politeness. From these statements, it will form a reinforcement toward an understanding and insight of thinking in a strong character and visionary, as revealed by an interview result of a student about the motivation to continue education until university.

"Motivasi saya di erah sekarang pendidikan itu penting. Kalau misalnya kita hanya *stag di situ saja kapan kita mau maju, makanya kita harus berusaha bagaimana caranya agar pendidikan kita terus berlanjut agar ilmu kita makin banyak dan insya Allah bermanfaat."

(Translation)

"My motivation in this era is education as an important thing. For instance if we are stuck in the same place, when do we move on, that is why we must try how to continue our education so that our knowledge is increased and by God's willing, it will be fruitful."

The interview result shows that the student views education as an absolute thing because it is one way to improve scientific competence. So, the way of thinking is imaging herself toward the understanding of educational progress that is efficient and effective.

As with the symbolic forms in PBI's discourse which its function confirms that character building through the provision of affirmation and motivation where there is an emphasis to influence the attitude and cognition of receivers. Empirically, Jufri \& Achmad Tolla's findings [1] explain that the power of symbolic meaning is used to influence the structure of public cognition, so it is not difficult to join the circle of domination and become obedient. This shows the similarity, that is the symbolic form used to affect attitudes and cognitions without feeling compelled. The difference is, presidential discourse influences public to form domination and power, while PBI's discourse forms ideas concerning obligation to legitimize lecturer's role to influence students to grow and shapes the character of scientists.

\section{CONCLUSION}

Based on the description that has been discussed in the previous section, it concludes eleven functions of symbolic forms regarding character building in PBI's discourse at IAIN Palopo as follows: (1) the statement of "challenging" characteristic and its development by representing an idea in the form of a competency sharpening; (2) giving direction, 
guidance, and advice by representing the idea of affirmation/motivation form; (3) giving praise by representing the idea of affirmation/motivation form; (4) giving threat (fear) by representing the idea of emphasis on affirmation/motivation form; (5) giving question and correction by representing ideas in the form of reinforcement and justification; (6) stating inadequacy and weakness by representing the idea of self-awareness toward the level of ability; (7) giving sanction (maintaining discipline) by representing the idea of giving awareness to udisciplined manner; (8) providing counseling and training service by representing the idea of strengthening deep competence; (9) giving an instruction or command by representing the idea of strengthening and affirmation; (10) declaring honesty by representing the optimal idea of material mastery; and (11) asking for request or demand by representing the idea of affirmation/motivation form.

\section{REFERENCES}

[1] Adisusilo, Sutarjo. (1914). Pembelajaran Nilai Karakter: Konstruktivisme dan VCT sebagai Inovasi Pendekatan Pembelajaran Afektif. Jakarta: Rajawali Pers.

[2] Badara, Aris, (2013). Analisis Wacana: Teori, Metode, dan Penerapannya pada Wacana Media. Jakarta: Kencana.

[3] Bogdan, Robert.C. and Biklen S.K. (1998). Qualitative Research for Education, An Introdaction to Theory and Methods. Boston: Allyn \& Bacon.

[4] Denzin, K. Norman \& Yvonna S. Lincoln. (2009). Hanbook of Qualitative Research. Diterjemahkan Dariyatno dkk. Yogyakarta: Pustaka Pelajar.

[5] Fairclough, Norman. (1989). Language and Fower. London and New York: Longman.

[6] Jufri \& Achmad Tolla. (2015). Studi Bahasa Kritis: dalam Wacana PresidenNo Title. Makkassar, Indonesia: Badan Penerbit UNM.

[7] Marzuki. (2015). Pendidikan Karakter Islam. Jakarta: Amzah.

[8] Moleong, Lexy J. (2011). Merode Penelitian Kualitatif. Bandung: Remaja Rosdakarya.

[9] Mulyana, Deddy. (2003). Metodologi Penelitian Kualitatif: Paradigma Baru dan Ilmu Sosial Lainnya: Bandung. Remaja Rosdakarya.

[10] Naim, Ngainum. (2012). Character Building. Jogjakarta: Ar-Ruzz Media.

[11] Ritzer, George. (2014). Teori Sosiologi: Dari Sosiologi Klasik Sampai Perkembangan Terakhir Postmodern. (Penerjemah Saut Pasaribu, Rh. Widodo, \& Eka Adi Nugraha) Yogyakarta: Pustaka Pelajar.

[12] Rusdiati, Suma Riella. (2003). Bahasa Pertarungan Simbolik dan Kekuasaan. Yogyakarta: Jurnal Basis.

[13] Sugiyono. (2011). Metode Penelitian Kuantitatif Kualitatif dan R\&D. Bandung: Alfabeta.

[14] Yule, George. (2014). Pragmatik. (Penerjemah Indah Fajar Wahyudi). Yogyakarta: Pustaka Pelajar.

[15] Zubaedi. (2011). Desain Pendidikan Karakter: Konsepsi dan Aplikasinya dalam Lembaga Pendidikan. Jakarta.

[16] Zuchdi, Damiyati \& Zuhdan Kun Prasetya, Muhsanatun Siasah Masruri. (2013). Model Pendidikan Karakter: Terintegrasi dalam Pembelajaran dan Pengemangan Kultur Sekolah. Yogyakarta: Baturetno, Banguntapan.

Sukirman was born in Walenrang, May 16, 1967. His educational background started from SD Negeri Bolong in 1983, SMPN Walenrang in 1985, SMA Negeri 1 Palopo in 1988. He took his Bachelor Degree in Department of Indonesian Language and Literature, Faculty of Literature, Universitas Hasanuddin in 1993. He then attended the pre-magister program at PPs Unhas in 1997 and Master Program in Indonesian Language Education and Literature at Universitas Negeri Makassar in 2000. In 2015 until now he has studied in Post Graduate Program of Universitas Negeri Makassar for his doctoral degree with the concentration of Indonesian Language Education. Since 2000 until now, he has been a lecturer at STAIN Palopo (now IAIN Palopo). Additional position he also held such as from 2002-2003 as Secretary of the Center for Community Service and Research, 2004-2010 as Chairman of the Department of Tarbiyah (Science and Teacher Training), 2010-2014 as Vice Chairman of Academic and Institutional Development at STAIN Palopo, 2002-2010 as Secretary of the Inspection Team of Scientific Research and Lecturer's Credit Point at STAIN Palopo, 2010-2013 as Head of Inspection Team of Scientific Research and Lecturer's Credit Point at STAIN Palopo. Some of the trainings that have been followed include ToT Lecturer's Learning Management at UIN Kalijaga, Research on Social Culture and Religious Sciences at Faculty of Cultural Sciences UGM. Written products that have been published include: Pengantar Bahasa Indonesia in 2010, Kunci Sukses Berbahasa Indonesia in 2010, Kategori Verba Bahasa Duri Pendekatan Generatif, IC-Analysis in 2012, Dasar-Dasar Memahami Bahasa Indonesia in 2014, Ontologi Puisi “Menanti Rindu di Atas Telapak Tangan” in 2014, Cara Kreatif Menulis Karya Ilmiah in 2015, and still actively doing researches and writing journals.

Jufri was born in Soppeng, December 31, 1959. His educational background involves in 1984 for Bachelor of Education of German/IKIP Ujung Pandang, in 1986 for Master Program in Indonesian Language Teaching and Education at Universitas Negeri Malang (completed in 1 year and 11 months), in 2006 taking his Doctorate Program and became as the $63^{\text {rd }}$ graduate from Stanford University (completed in 2 years and 11 months) with a dissertation entitled A Discourse of Lontara Structure of La Galigo with honors. Since 1985, he has been a lecturer at Foreign Language Education Department (FPBS) IKIP Ujung Pandang (now UNM). In 2002, he held the functional position of an Associate professor (IV/c) with full teaching authority and examined the course of Language Learning Research (Sprachlehr-Und Lernforschung) in the Department of Foreign Language Education (Germany), Faculty of Languages and Arts, Universitas Negeri Makassar. In addition, he attended German language education (Sprachkurz) in Iserlohn, Germany, 1987 and became a trainer (ToT) on HUMAN RIGHTS of NATIONAL POLICE Member (POLRI cooperated with Headquarters, UNHCR, and Ministry of Justice and HUMAN RIGHTS) in South Sulawesi, 2001-2002. For additional position, he was the Secretary of the German Language and Education Department, Head of the German Language Laboratory, and IGBJI's 
Secretary of South Sulawesi. Moreover, he also actively writes papers and becomes as a participant at various national and international seminars while writing a book entitled Prinsip Strategi Pembelajaran Bahasa.

Suradi Tahmir was born in Bone, April 13, 1964. His educational background from elementary to high school has been completed in Bone. In 1988, he completed his bachelor degree in Mathematics Education program at IKIP Ujung Pandang. In 19891990, he attended Pre-magister education program at ITB. In 1992, he completed master degree in Mathematics study program with the title of M.S. In 2005, he completed his doctoral degree in Mathematics Education at UNESA Surabaya. Since 1989, he has been a lecturer in Mathematics Education Study Program, FMIPA IKIP Ujung Pandang (now UNM). He also has experienced several positions that in in 1996-2000 as Secretary of Mathematics Education Department FPMIPA, in 2005-2006 as Head of Mathematics Education Program, in 2006-2010 as Head of Mathematics Education Study Program at PPs UNM, in 2010-2016 as Assistant Director I (Academic Section) at PPs UNM and Coordinator of Publication of PPs UNM Cooperation. In 2000, he became as Head Lecturer in Algebra and in 2007 as a Professor of Mathematics Education. Some of the trainings that have been followed include having apprenticeship of mathematics education research at ITB Bandung, mathematics workshop research at ITB, and Education MIPA laboratory management practice at UPI Bandung. Furthermore, some of his writings are Struktur Aljabar. In addition, he actively writes scientific papers and articles from various studies which published in several scientific journals, both national and international level. He is active as a participant and speaker at scientific meetings, both national and international level as well.

Mahmudah was born in Cantuk, Singojuruh Subdistrict, Banyuwangi, on February 12, 1967. Her educational background started from SD Negeri Lemahbang Dewo in 1981, MTs Negeri Cangkring Filial Banyuwangi in 1983, SPG Muhammadiyah II Banyuwangi in 1986. She took her Diploma Three program in 1989 concentrating in Indonesian Language Education at IKIP Makassar. In 1991, she completed her bachelor degree in Indonesian Language Education at IKIP Makassar. In 1995, she completed her master program at Indonesian Language at Universitas Hasanuddin. In 1997, she completed her doctoral degree in Linguistics at Universitas Hasanuddin. Several writing products from her are Penggunaan Bahasa Indonesia Masyarakat Desa Tertinggal di Kota Madya Ujung Pandang in 1995, Sikap dan Perilaku Bahasa Kelompok Sosial Menengah Masyarakat Kota Makassar terhadap Penggunaan Bahasa Indonesia Ragam Baku in 1997, Literasi Kritis Sebuah Tuntutan dalam Penumbuhkembangan Karakter Anak Kelas Rendah in 2017, and there are still papers that have been completed. Since 2000 until now, she has been a lecturer at Universitas Negeri Makassar. E-mail: mahmudah.mahfud@gmail.com 